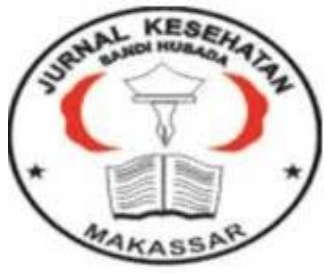

Jurnal Ilmiah Kesehatan Sandi Husada

hhttps://akper-sandikarsa.e-journal.id/JIKSH

Volume 9, Nomor 2, Desember 2020, pp 812-816

p-ISSN: 2354-6093 dan e-ISSN: 2654-4563

DOI: $10.35816 /$ jiskh.v10i2.414

\title{
Perbandingan Kecepatan Proses Penyembuhan Luka Swiss Webster dengan Kopi Robusta dan Arabika
}

Comparison of Swiss Webster's Wound Healing Process Speed with Robusta and Arabica Coffee

Arief Ristia Pangestu

Fakultas Kedokteran, Universitas Lampung

\section{Artikel info}

Artikel history:

Received; Juli 2020

Revised: Agustus 2020

Accepted; Agustus 2020

\section{Abstrak}

Serbuk kopi sebagai pengobatan luka sudah digunakan sebagai pengobatan tradisional hampir diseluruh dunia di perkebunan-perkebunan kopi. Hasil pengobatan luka menggunakan kopi tidak terlihat menimbulkan komplikasi infeksi. Kesulitan pengobatan berupa lamanya proses penyembuhan luka dan bahaya-bahaya lain yang dapat ditimbulkan oleh luka tersebut. Dari latar belakang tersebut peneliti bermaksud melakukan tinjauan literatur yang memiliki tujuan untuk mengetahui efek serbuk biji kopi Arabika dan Robusta dalam mempersingkat durasi penyembuhan luka pada mencit jantan galur Swiss webster. Metode yang peneliti gunakan yaitu studi literatur dari jurnal nasional dan internasional. Senyawa fenolik mengandung Phenolic Acid, yang terdiri dari Chlorogenic Acid, 3-Caffeoylquinic Acid, dan Hydrooxicinnamates, sebagai anti inflamasi. Hasil komponen asam klorogenat yang terkandung dalam senyawa fenolik untuk antiinflamasi dengan konsentrasi Green Coffea arabica adalah 4.1-7.9 (g/100g), Roasted Coffea arabica 1.9-2.5 (g/100g) dan Green Coffea canephora 6.1-11.3 (g/100g) dan Roasted Coffea canephora 3.3-3.8 (g/100g). Berdasarkan hasil tinjauan literatur kesimpulannya adalah senyawa fenolik kopi robusta lebih tinggi dibandingkan kopi arabika, sehingga proses percepatan penyembuhan kopi robusta lebih cepat.

Abstract

Coffee powder as a wound treatment has been used as a traditional medicine in almost all over the world in coffee plantations. The results of wound treatment using coffee do not appear to cause complications of infection. Treatment difficulties include wound healing and other dangers that can be caused by these wounds. From this background, the researcher asked to conduct a literature review which aims to see the effect of Arabica and Robusta coffee bean powder in shortening wound healing in male Swiss webster strains. The 
method that researchers use is literature study from national and international journals. Phenolic compounds contain Phenolic Acid, which consists of Chlorogenic Acid, 3Caffeoylquinic Acid, and Hydrooxicinnamates, as antiinflammatory. The results of the chlorogenic acid component contained in phenolic compounds for anti-inflammatory with a concentration of Green Coffea arabica are 4.1-7.9 (g/ $100 \mathrm{~g})$, Roasted Coffea arabica 1.9-2.5 (g / 100g) and Green Coffea canephora 6.1-11.3 (g/100g) and Roasted Coffea canephora 3.3-3.8 (g/100g). Based on the results of the literature review, the phenolic compounds of robusta coffee are higher than arabica coffee, so the healing process of robusta coffee is faster.

\author{
Keywords: \\ Robusta coffee; \\ Arabica coffee; \\ Phenolic compounds; \\ Wound healing;
}

Coresponden author:

Email: ariefristiap@gmail.com

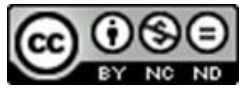

artikel dengan akses terbuka dibawah lisensi CC BY 4.0

\section{Pendahuluan}

Kopi merupakan salah satu tanaman yang secara empiris digunakan sebagai obat antibakteri (Nur, 2009). Menurut National Coffee Association United States (2011), Mengkonsumsi kopi yang merupakan sumber utama kafein meningkat sebesar $98 \%$ di Indonesia dalam 10 tahun terakhir. Serbuk kopi sebagai pengobatan luka sudah digunakan sebagai pengobatan tradisional hampir diseluruh dunia di perkebunan-perkebunan kopi. Sejak berpuluh tahun lalun penduduk di perkebunan kopi di Indonesia telah mengenalnya. Hasil pengobatan luka menggunakan kopi tidak terlihat menimbulkan komplikasi infeksi (Yuwono, 2012).

Kopi Arabika (Coffea arabica), kopi Liberika (Coffea liberica) dan kopi Robusta (Coffea robusta) merupakan beberapa jenis kopi yang paling banyak dibudidayakan di Indonesia.. Kadar kafein 2\%; minyak atsiri 10\% - 16\%; asam klorogenat $6 \%-10 \%$; zat gula $4 \%$ $12 \%$; selulosa $22 \%$ - 27\%; polifenol 0,2 \% yang terkandung dalam kopi Robusta (Najiyati dan Danarti, 2009). Kopi Arabika mempunyai kualitas yang tinggi dan memiliki aroma harum. Kualitas Robusta berada di bawah Arabika, dikarenakan cenderung berasa asam dan pahit, dan untuk kandungan kafein yang lebih tinggi (2-3 kali) dari Arabika (Redaksi Health Secret, 2012). Dibandingkan buah dan sayuran, kopi mengandung lebih banyak antioksidan. Beberapa senyawanya yaitu, polifenol, flavonoid, proantisianidin, kumarin, asam klorogenat, trigonelin dan tokoferol (Redaksi Health Secret, 2012 dan Sani, 2012).

Serbuk biji kopi Robusta terdapat didalamnya kandungan asam chlorogenic yang memiliki efek sebagai antioksidan dan mampu untuk melindungi tubuh dari efek radikal bebas, juga anti bakteri Methicillin Resistant Staphylococcus aureus (MRSA) (Aprianti, 2007 dan Nita, 2007). Kesulitan pengobatan berupa lamanya proses penyembuhan luka dan bahayabahaya lain yang dapat ditimbulkan oleh luka tersebut, berdasarkan permasalahan tersebut fokus peneliti yaitu melakukan tinjauan literatur yang bertujuan untuk mengetahui efek serbuk biji kopi Arabika dan Robusta dalam mempersingkat durasi penyembuhan luka pada mencit jantan galur Swiss Webster.

Luka timbul sebagai respon local dari suatu jaringan, dengan atau tanpa respon sistemik terhadap transfer energi dari sumber fisika (mekanik, termal, radiasi, elektrik) maupun sumber kimia. Dampak yang ada, merugikan bagi manusia baik secara psikologis maupun 
secara fisik (Ananta, 2020). Madu memiliki sifat anti-bakterial, anti-viral, anti-fungal, antioksidan, dan anti-inflamasi serta berperan menjaga kelembapan pada lokasi luka, dan menjadi batas protektif untuk meminimalisir kontak antara luka dengan agen infeksius. Penggunaan madu sebagai dressing terbukti efektif dan memperpendek masa penyembuhan ulkus diabetikum (Regia Divandra, 2020).

\section{Metode}

Metode yang digunakan merupakan studi literatur dari jurnal nasional dan internasional. Proses studi literatur dengan cara membaca, memahami, dan mereviewnya dari berbagai sumber yang ada. Tujuan dari metode ini ialah menyajikan dan menambah pengetahuan dan pemahaman kita mengenai topik yang dibahas dengan meringkas materi yang sudah diterbitkan juga informasi perihal fakta dan analisis baru dari tinjauan literatur yang telah relevan dan dibandingkan dalam artikel dengan hasil tersebut.

\section{Hasil Dan Pembahasan}

Kafein merupakan senyawa yang terpenting dalam kopi. Kafein (1,3,7-trimethylxanthine) termasuk dari golongan methylxanthine seperti theophylline (1,3-dimethylxanthine) dan theobromine (3,7-dimethylxanthine). Kafein berupa bubuk tidak berwarna, tidak berbau dan memiliki rasa agak pahit pada suhu ruang. Kafein larut dalam air mendidih tetapi pada suhu ruang, pelarut terbaik adalah kloroform (Higdon, 2006). Banyak penelitian mengungkapkan efek kopi terhadap kondisi medis tertentu, baik itu efek positif maupun efek negatif. Beberapa efek kopi terhadap kesehatan masih diperdebatkan. Beberapa efek positif kopi antara lain: menurunkan resiko penyakit alzhaimer, parkinson, diabetes mellitus tipe 2, sirosis hepar, kanker gaster, dan menurunkan asam urat darah. Beberapa efek negatif kopi antara lain; meningkatkan tekanan darah, menimbulkan ulkus peptikum, esophagitis erosif, gangguan ginjal, dan refluks gastroesophageal (Cavalcante, 2000, Gerhastuti, 2009 dan Fuentes, 2014).

Kopi sebagai antioksidan terdiri dari senyawa fenolik yang berfungsi sebagai perlindungan terhadap pengaruh oksigen radikal bebas sebagai antioksidan, sehingga dengan menghambar dari peroksidasi lipidnya dapat mengurangi teijadinya kerusakan sel (radical scavenger) (Yuwono, 2010). Senyawa yang terkandung dalam senyawa fenolik yaitu, Phenolic Acid, yang terdiri dari: Chlorogenic Acid, 3-Caffeoylquinic Acid, dan Hydrooxicinnamates, berfungsi sebagai anti inflamasi, yaitu mengurangi efek hislamin, bradikinin, dan lekotrien, dan sehingga pada akhirnya dapat mengurangi efek dari peningkatan permeabilitas kapiler selama fase inflamasi sehingga dapat mencegah keluamya makromolekul dari mikrosirkulasi dan juga dapat mengurangi dari pembengkakan (edema) yang ada (Yuwono, 2010).

Pratama dan Busman (2020, dikutip dari Gill, 2002 h. 4976-82) menyatakan antioksidan berdasarkan sumbernya dibagi menjadi 3 kelompok (anonim, 2012), yaitu 1) antioksidan endogen, merupakan antioksidan yang diproduksi didalam tubuh/ enzim antioksidan (Enzim Superoksida Diamutase (SOD)), Glutation Peroksidase (GPx), dan Katalase (CAT); 2) Antioksidan sintetis, banyak produk pangan yang menggunakan ini; 3) Antioksidan alami diperoleh dari tumbuhan dari semua bagiannya, dengan memiliki kandungan vitamin A, C ,E dan senyawa fenolik (Flavanoid).

Dan senyawa fenolik juga dapat mampu mengurangi aktivitas sistem komplemen. Telah diketahui bahwa faktor yang terpenting yaitu masalah pencegahan terjadinya kontaminasi bakteri dan infeksi dalam menjaminnya keberlangsungan penyembuhan suatu luka adalah. Sehingga suatu luka bisa sembuh kembali karena daya tahan (kemampuan) tubuhnya sendiri, namun juga dengan bantuan dari anti bakteri yang diberikan secara 
topikal. Proliferasi normal dari sel-sel jaringan untuk menutup luka bisa terjadi jika dalam pencegahan infeksi pada luka diutamakan sebagai prasyarat yang penting (Yuwono, 2010).

Setelah melewati fase inflamasi, proliferasi, dan maturasi akan melakukan homeostasis, trombosit, jala fibrin terbentuk, dan reaksi inflamasi dan terjadi pembentukan kolagen sedikit setelah terbentuknya fibrin. Penyembuhan luka adalah suatu bentuk proses usaha untuk memperbaiki kerusakan yang terjadi. Komponen utama dalam proses penyembuhan luka adalah kolagen disamping sel epitel. Fibroblast adalah sel yang bertanggung jawab untuk sintesis kolagen. (Perdanakusuma, 2007). Dan hal ini membuat penyembuhan luka menjadi lebih cepat durasi penyembuhannya.

Mencit (Mus musculus L.) mempuyai ciri-ciri yaitu bentuk tubuh kecil, berwarna putih, mempunyai siklus estrus teratur 4-5 hari. Kondisi ruang harus senantiasa bersih untuk pemeliharaan mencit (Mus musculus L.) kering dan juga jauh dari kebisingan. Suhu ruang pemeliharaan kisaran $18-19^{\circ} \mathrm{C}$ dan harus dijaga dan kelembaban udara antara $30-70 \%$. Umur paada mencit betina dewasa yaitu 35-60 hari dengan berat badan 18-35 g. Lama hidupnya 1-2 tahun, bahkan dapat mencapai 3 tahun. Waktu 1,5 tahun dibutuhkan mencit betina pada masa reproduksi. Mencit betina dan jantan dapat dikawinkan pada umur 8 minggu. Lama kebuntingan kisaran 19-20 hari. Rata-rata jumlah anak mencit adalah 6-15 ekor dengan berat lahir antara 0,5-1,5 g. Mencit sering digunakan dalam penelitian dan memiliki beberapa keuntungan yaitu daur estrus teratur dan dapat dideteksi, Relatif singkat pada periode kebuntingannya, dan memiliki anak yang banyak juga terdapat keselarasan pertumbuhan dengan kondisi manusia (Akbar, 2010) (Smith dan Mangkoewidjojo, 1988).

Komponen asam klorogenat yang terkandung dalam senyawa fenolik untuk antiinflamsi dengan konsentrasi Green Coffea arabica adalah 4.1-7.9 (g/100g), Roasted Coffea arabica 1.9-2.5 (g/100g) dan Green Coffea canephora 6.1-11.3 (g/100g) dan Roasted Coffea canephora 3.3-3.8 (g/100g) (Farah, 2012). Berdasarkan hasil tinjauan literatur yang dilakukan, senyawa fenolik yang mengandung phenolic acid terdiri dari Chlorogenic Acid, 3-Caffeoylquinic Acid, dan Hydrooxicinnamates dari kopi robusta lebih tinggi dibandingkan kopi arabika, sehingga proses percepatan penyembuhan kopi robusta lebih cepat dibandingkan arabika.

\section{Simpulan Dan Saran}

Kopi bisa digunakan dalam proses percepatan penyembuhan luka dan tidak menyebabkan komplikasi suatu infeksi. Dan senyawa fenolik pada kopi yang mengandung Phenolic Acid ( Chlorogenic Acid, 3-Caffeoylquinic Acid, dan Hydrooxicinnamates) berfungsi baik sebagai anti inflamasi, dan dapat mengurangi efek dari peningkatan permeabilitas kapiler pada fase inflamasi. Semakin tingga senya fenolik yang terkandung dalam suatu kopi, proses antiinflamsi bisasemakin cepat seperti pada kopi robusta dibandingkan dengan kopi arabika.

\section{Daftar Rujukan}

Akbar B. 2010. Tumbuhan dengan senyawa aktif yang berpotensi sebagai bahan antifertilitas. Jakarta: adabia press.

Aprianti Y. 2007. Kopi robusta. http://www.kompas.com. Diunduh 14 November 2018.

Ananta, G. P. (2020). Potensi Batang Pisang (Musa Pardisiaca L.) Dalam Penyembuhan Luka Bakar. Jurnal Ilmiah Kesehatan Sandi Husada, 11(1), 334-340

Cavalcante JWS, Jr PRMS, Menezes MGF, Marques HO, Cavalcante LP, Phacheco WS. Influence of caffein on blood pressure and platelet aggregation. Arq bras cardiol. 
2000;75(2):102-5.

Farah A. 2012. Coffee :EmergingHealth Effects and Disease Prevention, First Edition. USA: John Willey \& Sons, Inc and Institute of Food Technologists (USA) Wiley- Blackwell Publising Ltd.

Fuentes E, Caballero J, Alarcon M, Rojas A, Pamolo I. 2014. Chlorogenic acid inhibits human platelet activation and thrombus formation. Plos one. Vol. 9(3): E90699.

Gerhastuti BC. 2009. Pengaruh pemberian kopi dosisbertingkat per oral selama 30 hari terhadap gambaran histologi ginjal tikus wistar (skripsi). Semarang: Fakultas Kedokteran Universitas Diponegoro.

Gill, M.I., Tomas-Barberan, F.A., Hess-Pierce, B. and Kader, A.A. Antioxidant Capacities, Phenolic Compounds, Carotenoids, and Vitamin C Contents of Nectarine, Peach, and Plum Cultivars from ='in California, J. Agric. Food Chem. 2002; 50 (17), pp. 4976-82

Higdon J, Frei B. 2006. Coffee and health: a review of recent human research. Crit Rev Food Sci Nutr 46: 101-123.

Najiyati S, Danarti. 2009. Kopi: Budidaya dan Penanganan Lepas Panen. Jakarta: Penebar Swadaya.

National Coffee Association USA. 2011. What is coffee?. http://www.ncausa.org/i4a/pages/index.cfm?pageid=67. Diunduh 20 November 2018.

Nur IM. (2009). Aktivitas Antibakteri Ekstrak Metanol Bunga Pepaya Jantan (Carica papaya L) Terhadap Echerichia coli Dan Staphylococcus aureusMultiresisten Antibiotik. Skripsi Tidak Diterbitkan Surakarta: Fakultas Farmasi UMS Surakarta.

Nita. 2007. Asam chlorogenic. http://www.majalahfarmacia.com/rubrik/one_finenews.asp? ID news=38. Diunduh 18 November 2018.

Perdanakusuma DS. 2007. Anatomi Fisiologi Kulit Dan Penyembuhan Luka. Surabaya: Plastic Surgery Departement, Airlangga University School of Medicine- Dr. Soetomo General Hospital, Surabaya. h. 3

Pratama AN, Busman H. 2020. Potensi Antioksidan Kedelai (Glycine Max L) Terhadap Penangkapan Radikal Bebas. Jurnal Ilmiah Kesehatan Sandi Husada 11(1): 497504

Redaksi Health Secret. 2012. Khasiat Bombastis Kopi. Jakarta: Elex Media Komputindo; p. 13, 22-23, 27-29, 37, 97, 128-9.

Regia Divandra, C. V. (2020). Madu Sebagai Dressing Pada Penyembuhan Ulkus Diabetikum. Jurnal Ilmiah Kesehatan Sandi Husada, 11(1), 533-539.

Sani A. 2012. Manfaat Kopi untuk Kesehatan. http://dokter-herbal.com/manfaat-kopiuntuk-kesehatan.html. Diunduh 15 November 2018.

Smith JB, Mangkoewidjojo S. 1988. Pemeliharaan, Pembiakan Dan Penggunaan Hewan Percobaan Di Daerah Tropis. Jakarta: UI Press. h. 37-57.

Yuwono HS. 2010. Sains dan Pengalaman Praktis. In: N. F. Atif, ed. Ilmu Bedah Vaskuler. Bandung: PT Refika Aditama.

Yuwono. 2012. Staphylococcus aureus dan Methicilin-Resistant Staphylococcus aureus (MRSA). Palembang: Departemen Mikrobiologi FK Unsri. 